\title{
El humor como vestíbulo del clímax trágico en un relato de Julio Ramón Ribeyro
}

\author{
Belén Vila Osores \\ Consejo de Educación Secundaria. Uruguay \\ belen666333@hotmail.com
}

\section{Resumen}

Analiza un episodio bufonesco en la diégesis de un cuento limeño intitulado "Mientras arde la vela”, de Julio Ramón Ribeyro. El propósito es detectar un incidente cómico que funcione como espacio vestibular de clímax trágico, en el contexto de un relato urbano caracterizado por amparar comarcas temáticas como la alienación, la resignación, el desamor, la somnolencia. La risa en este episodio conlleva el dolor, lo cómico lleva implícito lo trágico. A estos presupuestos teóricos se asocia el estudio filosófico acerca del desnivel que produce la risa, y que es abordado por Alfred Stern y Henri Bergson. Estos diálogos permiten comprender la función del recurso del humor en el texto, previo al momento trágico que se desencadenará en el desenlace.

Palabras clave: Humor, Llanto, Carnavalización, Grotesco, Ribeyro

\begin{abstract}
Analyzes an episode clownish in the Diegesis of a tale Lima titled While the Candle Burns, by Julio Ramón Ribeyro. The purpose is to detect a comic incident that works as a vestibular space of tragic climax, in the context of an urban narrative characterized by covering thematic regions such as alienation, resignation, Dislove, drowsiness. The laughter in this episode carries the pain, the comic implies the tragic. To these theoretical budgets is associated the philosophical study on the unlevelness that produces the laughter, and which is approached by Alfred Stern and Henri Bergson. These dialogues make it possible to understand the function of the resource of humour in the text, prior to the tragic moment that will be unleashed in the outcome.
\end{abstract}

Keywords: Humour, Crying, Carnivalization, Grotesque, Ribeyro 


\section{El humor como vestíbulo del clímax trágico en um relato de Julio Ramón Ribeyro}

\section{La introducción en el contexto de un relato urbano}

Al recorrer las librerías céntricas de dos ciudades latinoamericanas Montevideo y Lima y en la búsqueda de investigar para esta comunicación, advertí que no se encontraban fácilmente libros contemporáneos sobre el humor. La pregunta que inmediatamente formulo es, qué sucede con los lectores de estas metrópolis, acaso ¿no ríen? Quizás esto responda a que en estas ciudades el sujeto se somete a la demanda constante de la vida moderna, tal como Pablo Neruda lo anota en los versos de la primera estrofa de Walking around. Poema surrealista que describe al hombre que camina alrededor de sí mismo, sumergido por las actividades que ayudan a olvidar el pasmo de un "caminar" aburrido, una identidad difuminada en espacios que se masifican (sastrerías y cines). Ante los deberes laborales que no siempre concuerda con la economía recibida a cambio, las responsabilidades que conlleva sustentar una familia, las múltiples y continuas exigencias que demanda la sociedad, el hablante lírico se desorienta y sonríe menos.

Ante este contexto ¿es posible el diálogo fluido entre sujeto y humor? ¿Dónde se aloja el espacio para la risa? ¿Acaso el limbo es la zona válida para sonreír?

El propósito de este trabajo no es localizar la alegría universal y positiva que se aloja en el mejor de los mundos posibles, tal como lo percibía el Cándido (1759) de Voltaire, tampoco se elige la escena del relato para estudiar solo el asfixiante y negativo espacio aéreo. Más bien detecta un incidente cómico que funciona como espacio vestibular de clímax trágico en el contexto de un relato urbano caracterizado por amparar comarcas temáticas como la alienación, la resignación, el desamor, la somnolencia. La risa en este episodio conlleva el dolor, lo cómico lleva implícito lo trágico. 
Se recordará a las obras Tartufo (1664), Enfermo imaginario (1673), del dramaturgo francés conocido con el nombre de Moliére (1622-1673), los personajes protagónicos afirman lo que no son, la inconsecuencia (moral, religiosa) forma parte del recurso técnico que se repite en sus obras. Así, el episodio ribeyriano propone la gracia para que ocupe una zona vestibular, que gravite en torno al preámbulo de la tragedia, se entiende así el espacio como el "ámbito de todas las posibilidades (...) caótico (...) cósmico” (Cirlot, 1992, p. 190). Potencias que dejan de permanecer vacías para ocuparse de las imágenes que Gastón Bachelard en el desarrollo de La poética del espacio y en El agua y los sueños, analiza. El autor repara en el universo de los íconos y sus connotaciones particulares, en textos que corresponden a poéticas líricas, narrativas de autores literarios y filósofos. Manifiesta que en el espacio habitan imágenes felices con valores positivos e imágenes infelices con valías negativas.

Afortunadamente, como dice Stern todavía "reímos con más frecuencia de la que lloramos" (1950, p. 31). Y es en ese sentido y territorio fronterizo que se proyecta esta comunicación.

De acuerdo con Henri Bergson en su estudio clásico de La risa, subraya que no es fácil definirla, dado que la misma se ubica en las demarcaciones de lo cómico y lo trágico. El pensador inicia una cartografía filosófica y se detiene en las paradojas de la risa y el llanto, así como en la degradación y pérdida de valores, la debilidad humana y la broma, abecés que se manifiestan en el relato de Julio Ramón Ribeyro. Este contraste de elementos y claroscuros que interactúan en una escena cotidiana produce sorpresa, así como lo ocasiona un disfraz, no obstante que nadie lo lleve puesto. Si se visualiza un traje de Superman en alguien que no lo luce bonito genera una infracción. Alteración que se efectúa también en el ejemplo de la nariz de payaso que propone Stern. Esto es, al imaginar una situación hilarante compuesta por alguien (un payaso, un cómico) en un contexto determinado que lleva puesta una protuberancia redonda y roja en medio de la cara, de pronto, puede volverse una carcajada si el sujeto receptor piensa (traslada mentalmente el disfraz) que quien se la coloca no es el payaso sino una persona conocida, un amigo que queremos, una persona que no se tolera, etc. Este acontecimiento vivido y recreado en la mente estimula a la sonrisa porque "un hombre que se disfraza es una figura cómica. También lo es un hombre que parece haberse disfrazado" (Bergson, 1985, p. 23).

A este desajuste, Tzvetan Todorov en un artículo que propone para Comunicaciones le denomina infracción, se trata de un espacio que da lugar a un nuevo orden, y hace referencia al criterio tipológico que surte impresión cuando se introduce un desvío en la diégesis del discurso, donde irrumpe el humor.

¿Cuál es la técnica que emplea Julio Ramón Ribeyro para inducir a la risa al espectador? Lo que motiva la risa es la recurrencia, es esa linealidad en el chiste equivalente a lo que Violette Morin llama la "constancia de construcción” (Barthes 
y otros, 1970, p. 121). Con Morin coincide Bergson, acerca del efecto que produce la periódica repetición de los movimientos que realiza el personaje pícaro caracterizado por una doble moral. Esta muletilla histriónica resulta de una combinación de gestos y actitudes que efectúa Moisés o por circunstancias no buscadas, repetidas, fortuitas como esta escena:

Si un día me encuentro en la calle con un amigo a quien no veía desde mucho tiempo, nada tendrá de cómico esta situación. Pero si el mismo día me lo vuelvo a encontrar por segunda, por tercera y hasta por cuarta vez, acabaremos los dos por reírnos de la coincidencia. (Bergson, 1985, p. 36).

La repetición y la inversión son dos de los procedimientos que aparecen en Mientras arde la vela, episodio que ocupa a esta comunicación. El primer recurso responde a la búsqueda voluntaria o involuntaria del chiste pero que se obtiene por reincidencia. Mientras la segunda técnica llamada de "inversión", interviene cuando se suscitan situaciones que se estiman extrañas a la lógica de la verosimilitud ficcional, por ello, Mijail Bajtín y Henri Bergson consideran a aquellos sucesos como creíbles en "el mundo al revés". Esta alteración pronuncia el relieve de la secuencia, promoviendo un efecto inesperado en el lector.

El episodio que se invoca es cuando Panchito, el hijo de Mercedes y Moisés actúa dándole sugerencias a su madre. Le dice qué es lo que está sucediendo con el padre y le advierte que no está muerto y frente a esa situación la somete a un interrogatorio acerca de cómo siguen las cosas a partir de allí. El niño es quien aconseja al adulto. Sin embargo, lo esperado es que la madre fuera quien administrara y ejecutara las resoluciones tomadas por ella misma.

Ribeyro invierte los roles, recurso que causa humorada, y que anteriormente ha sido empleado por la novela picaresca. En El lazarillo de Tormes, y a lo largo de los tratados de este texto anónimo, el listo (Panchito emite indicios en su temprana edad de forjar poco a poco, aunque sin pausa una personalidad de pícaro) asume conductas repetidas pero que pule y evoluciona para sobrevivir en la vida. Frente a los diferentes amos, el protagonista simula un recto comportamiento que lo utiliza para conseguir el trabajo que se propone obtener.

Bergson encuentra en el gesto de esa repetición, respecto a lo cómico, "es automatismo instalado" (Stern, 1950, p. 38) afirma. La gracia que provoca Moisés, que es el personaje que se abordará, es especial, porque linda con lo trágico, con lo doloroso del mundo, como plantea Nietzsche "el animal más desdichado y más melancólico es también [...] el más alegre” (ibid., p. 32).

En definitiva, el espectador espera una y otra vez que Moisés aparezca en escena porque le ha acostumbrado a mantener las expectativas entre lo cómico y lo trágico, dado que cada vez que él aparece en medio de la escena dramática (pathos) algo jocoso ocurre. 


\section{El colectivo que merodea a la historia}

El cuento con el que se trabaja se titula Mientras arde la vela, el argumento versa acerca de una historia limeña y particular, pero que resulta conocida para el lector, independientemente de dónde se encuentre, por ese motivo puede tratarse de grupos familiares que habiten otras localidades.

El cuento pertenece al breviario Los gallinazos sin plumas de Julio Ramón Ribeyro $^{1}$ (Lima, 1929-Lima, 1994) autor que vivió en Perú, pero también en Europa. Imbuido del "sentimiento de carencia de un espacio propio" (Navascués, 2004, p. 12) construyó un imaginario poético con un lenguaje culto, - aunque habla de la marginalidad y los laterales de la ciudad limeña, no reproduce el habla del lugareño - desde la distancia, evoca el recuerdo y consulta las cartas enviadas desde Lima, por su hermano Juan Antonio, que a veces publica por decisión propia, omitiendo consultar a Julio Ramón, tal es el caso de Interior " $L$ ", pero que este agradecerá infinitamente.

Antes de ingresar al estudio específico del microepisodio, es menester ubicar a Ribeyro en la Generación del cincuenta (1950) — previa al conocido boom literario-. Este colectivo nace en la Universidad Nacional Mayor de San Marcos en Lima, los primeros esbozos y artículos literarios de los escritores que asoman a la esfera intelectual por aquella época aparecen, aproximadamente, cinco años antes de la fecha indicada, y su ocaso ${ }^{2}$ se determina alrededor de los años sesenta.

Los exponentes peruanos ${ }^{3}$ que contribuyen a aportar textos literarios - se nombran solo algunos - leen a Miguel de Cervantes Saavedra, Azorín, James Joyce, Ernest Hemingway, William Faulkner, Franz Kafka. De los autores franceses naturalistas y realistas, optan por Honoré de Balzac, Stendhal, Gustave Flaubert, Marcel Proust, Guy de Maupassant. De los escritores rusos eligen las lecturas de Fiódor Dostoyevski, Nikolai Gógol, León Tolstói o Antón Chéjov.

La Generación del cincuenta renueva la temática literaria peruana, deja atrás la región y su naturaleza, opta por mirar a la ciudad como el gran espacio que se metamorfosea y se vuelve a fundar. Desde la escritura, instauran renovaciones técnicas, que se aproximan a las elaboradas por los escritores norteamericanos pertenecientes a The lost generation. Entre otras innovaciones que aportan, se encuentra el

1 Se sugiere ver el mapa interactivo donde se hace un recorrido guiado que incluye años de infancia, juventud y muerte. Lo ofrece el Diario El Comercio de Perú en la URL: <http://elcomercio.pe/ julio-ramon-ribeyro/recorrido/>. Consulta: 31/3/16 a las 10:12 horas.

2 Carlos Eduardo Zavaleta, es escritor de esta generación y por tanto testigo directo, se le sigue a él para construir en este documento las fechas que delimitan a la generación del cincuenta en el Perú.

3 Peter Elmore confecciona una lista de narradores donde nombra a Ribeyro como "el más importante de la promoción” y continúa con Eleodoro Vargas Vicuña, Sebastián Salazar Bondy, Carlos Eduardo Zavaleta y Enrique Congrains (2002, p. 9). La lista es más extensa. 
estudio profundo de la psicología de los personajes, "la presión de los hechos sobre las personas", sus relatos "podrían definirse [...] como la historia psicológica de una decisión humana” (Ribeyro, 2003, p. 47).

La poética ribeyriana se conecta con el cuento a partir de la presencia del lector, y lo hace a lo largo de todo el desarrollo de la historia, pero es en el desenlace cuando aparece el vínculo más estrecho, el espacio vacío que llena y completa el receptor permite cerrar el horizonte de expectativas que se inició en la primera línea. Ribeyro define al relato como un reflejo de sí mismo, que capta y representa a partir de su niñez:

(...) de acuerdo a mi propia sensibilidad, lo merecía: oscuros habitantes limeños, escenas de la vida familiar (...) el mar y los arenales, combates perdidos, militares, borrachines (...) escritores, hacendados, matones y maleantes (...) pero también Europa y mis pensiones y viajes y algunas historias salidas solamente de mi fantasía (Ribeyro, 1994, p. 8).

De todos estos habitantes se nutre el breviario. Casi todos los relatos son forjados desde una impronta ficcional o desde un vértice (leyenda, anécdota personal infantil) que acaricia la realidad.

La literatura se convierte en un rito riguroso y perfectible, Ribeyro busca la superación de su propia escritura, en La tentación del fracaso (2003) escribe "¡Hay que trabajar, hay que trabajar!” (ibid., p. 33) para lograr la buscada y obsesiva perfección de la técnica, insiste y asegura que su "última preocupación ha sido vigilar el estilo y mantener cierto nivel de gusto literario [...] Las ideas pasan, la expresión queda" (ibid., p. 47-48).

\section{Categorías que intervienen en el relato}

Stern supone un principio para comenzar a entender el proceso de la "risa", como fenómeno emotivo ligado a determinados bienes, es entonces una "reacción instintiva frente a una degradación de valores" (1950, p. 73), aunque no siempre la degradación hace reír - a alguien puede no causarle gracia - en otras ocasiones puede hacer llorar.

La teoría de Stern - abreviándola - se asienta en que los chistes se vinculan con los valores y que estos buscan ser degradados. Y existen tantos chistes como valores existentes, y cuantos más valores se menoscabe, mayor será la gracia que causará (1950, p. 126). La risa que produce el episodio en cuestión deviene de las debilidades - que son muchas- que presenta el sujeto.

En el plano de lo real, la degradación de valores se presenta cuando alguien se equivoca y pronuncia una palabra en voz alta que tiene connotación negativa; 
en otro ejemplo que propone Stern el desnivel se produce cuando alguien que va caminando por la acera naturalmente se cae y no llega a lastimarse.

Los valores en el sujeto que cae no se pierden, sino que se desplazan porque escapa a su voluntad, lo mismo sucede con la fealdad (un sujeto feo) o la enfermedad (un sujeto enfermo). Si la persona que cayó se lastimó, entonces se efectúa la pérdida y aparece el dolor, que a veces se continúa en llanto, en este punto se supone que ya nadie se ríe, de lo contrario la persona que se ríe se arriesga a devaluarse a sí misma. La frontera que deslinda el llanto de la risa es dinámica, fluctúa, así como hay muchas formas de llanto hay muchas formas de reír y también de reír para después llorar.

Ahora bien, en el plano de la ficción esta situación cambia completamente, aún más si se trata de un espacio festivo sin reglas oficiales, pero con normas impuestas y por tanto democráticas para el pueblo como lo es el carnaval. En este reducto de lo cómico se permiten y se toleran todas las variaciones de las risas, incluidas las del receptor, que al fin y al cabo es un actor más. Esta conceptualización de lo carnavalesco acuñada por Mijail Bajtín, se celebra en un recodo aparte, que excluye todo protocolo que las instituciones Estado o Iglesia (principalmente el autor estudia el humor en Rabelais, y recorre el Medioevo, el Renacimiento) consideren como oficial.

La escena que ocupa esta comunicación se sitúa en un espacio donde se suspende el cronotopo real, concepto acuñado por Mijail Bajtín que refiere al tiempo-espacio, "a la conexión esencial de relaciones temporales y espaciales" (1989, p. 237) en la literatura. Todo lo que sucederá en la habitación familiar de Mercedes y Moisés mientras dure la escena, es carnavalesco. El carnaval funciona en un reducto simbólico donde las coordenadas de tiempo y espacio (cronotopo) se disuelven mentalmente. Las fiestas impuestas por el canon matizan el cronotopo, pero no lo suspenden, en cambio sí lo efectúa la carnavalización, que a su vez permite una vida alterna.

El teórico ruso resuelve así el conflicto polarizado entre los alejados polos considerados como sacros y profanos, creando un concepto tomado del espacio real e integrando a los dos extremos. Agrupa entonces, diferentes clases sociales, reúne lo grosero con lo sagrado, lo gracioso con lo grotesco, lo trágico con lo cómico, simbiosis que amalgama al episodio que protagoniza Moisés.

Esta inversión del mundo también la realiza el sistema de lo grotesco, que es la estética del "mundo al revés" (Bajtín, 2003, p. 13). Se desarrolla durante la Edad Media “y alcanza su epopeya artística en la literatura del Renacimiento” (ibid., p. 30).

El adjetivo grotesco deviene de "gruta", palabra que indica el lugar en donde se encontraron algunas pinturas italianas, que mostraban como impulso nuevo las fusiones de figuras mitológicas como la de los reinos vegetales, animales, humanos. 
El dinamismo de las formas en la que se traduce el sistema de lo grotesco recuerda al manierismo en las estampas del fresco titulado El Incendio del Borgo (1514) adjudicado al taller de Rafael.

El régimen del grotesco presenta dos vértices contradictorios pero que se suceden, aunque cuando aparece uno falta el otro. La muerte y la vida, el llanto y la risa, se presentan en una lucha denodada, es en ese contraste como se comprende la inconsciencia de Moisés y su repentino despertar. El momento en que se revela la anagnórisis, se produce tensión en el espectador, y dentro de la ficción sacude a la turba de vecinos que velaban al presunto muerto.

A lo largo de la escena carnavalesca el humor grotesco se erige.

\section{Al rescate del humor}

Hablar del humor en el breviario Los gallinazos sin plumas ${ }^{4}$ (1955) de Julio Ramón Ribeyro $^{5}$ no es tarea fácil dado el desencanto natural con el que deambulan los personajes de la ciudad ficcional o mítica de la que habla el autor, y que representa a la capital de Perú, Lima, que en constante progreso se aleja de la fantasía inicial e idílica que liga a las civilizaciones en el origen, lo mítico se instaura en el primer volumen como el espacio canonizado deseado, "esta irrupción de lo sagrado la que fundamenta realmente el Mundo y la que le hace tal como es hoy día" (Eliade, 1991, p. 7). El progreso, la tecnología, la multitud de personas se apiñan en la ciudad que crece desde el centro a las periferias. $\mathrm{Y}$ en los laterales se forjan las historias de los gallinazos "desplumados", seres que finalmente asumen "que nunca se alcanza la meta deseada" (Navascués, 2004, p. 117) pero que a pesar de todo "se debe seguir viviendo" (ibid., p. 117).

El cuadro de los personajes, se dividen en masculinos y femeninos. Los "seres de papel" masculinos sobrepasan ampliamente a la cantidad de personajes femeninos, que pululan en el breviario. Vale aclarar que Luisa y Estrella aparecen En la comisaría y El primer paso, para espolear a los hombres a que vuelvan hacia ellas, funcionan como motivos exteriores que impulsan algunas de las decisiones humanas y masculinas. En el relato que aquí se depara, Mercedes tiene una fuerza de voluntad que también la comparte María, una joven provinciana, que aparece en $\mathrm{La}$

4 Breviario donde aparecen — dependiendo de la edición - ocho relatos, que se sitúan en el siguiente orden, "Los gallinazos sin plumas" es el primero, que lleva el mismo nombre de la colección y en particular es el cuento que más le gustaba al autor (Esteban, 2014, p. 47). El segundo se titula "Interior 'L", le siguen "Mar afuera, Mientras arde la vela", "En la comisaría", "La tela de araña", "El primer paso", y el último "Junta de acreedores".

5 Autor de origen peruano, que se trasladó a Europa mediante la obtención de un subsidio para estudiar periodismo. Una vez terminado el apoyo económico que le otorgaba la beca, Ribeyro debió emplearse en diversos trabajos para amortiguar su estada en países europeos. Entre España, Madrid precisamente y Francia, París, escribe el conjunto de relatos Los gallinazos sin plumas, metáfora que señala la carencia —en todos los ámbitos— de los habitantes que viven en la periferia de la ciudad. 
tela de araña. Son las únicas mujeres que a pesar de la situación marginal que habitan buscan como pueden y en la medida de lo posible cambiar el entorno en el que viven. Mercedes diseña para sí misma como mecanismo de defensa, un imaginario mental que la empuja a soñar para salir del encierro que le produce la habitación de su hogar. Al frente de ella y a modo de espejo se encuentra su esposo Moisés, que devuelve la imagen deteriorada de Mercedes, y por contraposición refracta la deformidad (lo grotesco), es quien contribuye a crear los únicos episodios de humor que sobresalen en la diégesis del relato.

La función que cumple el humor es la de distender la tirantez, que se suscita en el sórdido ambiente interior de la pieza como del patio exterior que continúa a la habitación principal.

Stern repasa una nómina de escritores que han intentado explicar la risa, Aristóteles, Platón, Descartes, Bergson, Kant, Freud, entre otros, analiza la oposición optimismo (risa) versus pesimismo (llanto, lo trágico), y observa que se debe aprender de los dos.

La risa como el llanto se manifiesta a través de diversas expresiones. Si se recuerdan algunos de los antecedentes de lo cómico, se piensa en las obras de Aristófanes donde se ubican pícaros y dioses en el mismo nivel; el estagirita Aristóteles en La poética examina a la comedia y la sitúa por debajo de la tragedia, expone que aquella es una imitación de hombres inferiores. Hasta el momento todo indica que lo serio no convive armónicamente con lo cómico, Bajtín lo resuelve proponiendo la "carnavalización" como categoría de palabra.

Este concepto otorga una amplia licencia o aval a todos aquellos participantes que concurren a la fiesta. Además, como lugar de encuentro brinda y extiende una súbita y relativa libertad, en síntesis, sugiere un cruce de lo público con lo privado, pero no para confrontarse sino para dialogar. El teórico ruso señala que es en el transcurso del carnaval cuando "la vida misma" se interpreta, "y durante cierto tiempo el juego se transforma en vida real” (Bajtín, 2003, p.10).

A continuación, se depara en el estudio del episodio, para concluir con la antesala de lo trágico.

\section{El episodio en sí mismo}

El argumento del relato Mientras arde la vela versa sobre una familia tradicional, compuesta por los padres que se llaman Moisés y Mercedes, y el hijo de ambos al que apodan Panchito.

Sucede que Moisés no colabora en nada con su familia. Si no se duerme repentinamente se aburre de todo, de su trabajo, de sus quehaceres diarios en el hogar, incluso de su propio hijo. Moisés no depara en Panchito, no lo cuida ni protege; 
no lo acompaña en el crecimiento debido, a veces se aburre de "dar vueltas por el cuarto, dirigió un puntapié a Panchito que huyó hacia el patio chillando" (Ribeyro, 1994, p. 52). Sólo le interesa beber bebidas alcohólicas y dormir: "con el pecho descubierto roncaba mirando el techo", unas horas antes "yacía en la cama como ahora, pero estaba inconsciente", su esposa contemplaba "cómo roncaba, ahora, los ojos entreabiertos" (ibid., p. 51). De esta manera, el personaje grotesco queda expuesto ante el receptor, que una vez que lo conoce espera que asome.

El juego de matices y contrastes se presenta a partir del título, la iluminación - de la vela - fascina y hace daño, desde el inicio, cobra distintos colores una "llama azul [...] la débil luz" (Ribeyro, 1994, p. 51) y a medida que el desarrollo del relato avanza, la llama adquiere vida propia, se asemeja a un reptil, se ondula y enrosca. Es un elemento simbólico que brilla por sí misma y transmite una luz tenue. Al iluminar la zona esclarece lo alumbrado, y al mismo tiempo presagia lo trágico, es decir, al apagarse, otra vez da vida a la nocturnidad.

El título del relato refiere a la instancia en la que transcurre el relato e "indica enigmáticamente un lapso en el cual algo sucede, no mide en verdad el tiempo de una aventura sino la duración de un recuerdo" (Elmore, 2002, p. 49).

Mientras arde la vela Mercedes imagina, se evade del presente que la asfixia a través de la ensoñación. Sueña despierta con que sus manos agrietadas por lavar ropa se mejorarán pronto, anhela concretar el negocio propio, pretende ser dueña de una verdulería que montará gracias a un supuesto dinero que Moisés tiene ahorrado, aunque debido a las características intrínsecas de su esposo es factible que ese ahorro ya no exista. Entre sus metas aspira a que Panchito crezca y se realice como profesional, hasta concibe mentalmente la posibilidad maquiavélica de que su esposo desaparezca.

El episodio bufonesco del relato que ocupa a esta comunicación se inicia cuando Moisés interrumpe espontáneamente en la escena, emerge con un mandil blanco y un gorro, dando brincos, unos detrás de los otros, sosteniendo entre sus manos sucias un periódico encendido: "-Luz, luz -gritaba- [...] y por el labio leporino le saltaba la baba" (Ribeyro, 1994, p. 52). Moisés se comporta de forma extremadamente inmoderada, Bajtín enuncia al respecto que "el tema de la locura, por ejemplo, es muy típico del grotesco, ya que permite observar al mundo con una mirada diferente" (Bajtín, 2003, p. 36) aporta un orden nuevo, fuera del considerado universo corriente, "normal".

En el planteo de Stern se compara la perfección (valor positivo) con la imperfección (valor negativo), por tanto, el resultado entre los polos positivo y negativo es hacer notar que la imperfección es una degradación del valor positivo (Stern, 1950, p. 88).

De esta manera se abre la escena del relato, la figura principal de Moisés se alza en frenesí, en una actitud de algarabía busca la luminosidad que contiene el fuego. 
Con el afán de incendiar la habitación, es que conduce a la extrema desesperación a Mercedes “-Estaba como loco" (Ribeyro, 1994, p 52) repitió dos veces su mujer.

En ese borde de la situación, ella intenta detenerlo, pero como no lo logra, lo empuja para quitarle la "antorcha", así Moisés cae al suelo y se golpea la cabeza quedando inconsciente. Mercedes rápidamente comunicará este hecho a la vecindad, situación que hace pensar en el inmediato fallecimiento del papá de Panchito.

Por la manera en que cae al suelo y "junto a las manchas oscuras de humedad, estaba la huella que dejó la cabeza" (ibid., p. 52) como no respiraba y "la baba le salía por el labio roto" (ibid., p. 52) su esposa creyó que había fallecido. Panchito comprueba la veracidad del hecho y como su padre no contesta, con indiferencia se aparta de él. Es que él está acostumbrado a recibir patadas que su padre le propicia cuando se aburre, entonces Panchito le devuelve ahora el afecto de la misma manera y en la misma proporción que lo recibe. Callado se retira y se desatiende del accidente, para jugar con su trompo mágico que lo eleva a una dimensión de sueños desde un rincón.

A partir de allí los vecinos asustados se acercan al "cadáver" (ibid., p. 54) a proferir condolencias, los niños entran a la habitación familiar, aunque al ver "el perfil del muerto" (ibid., p. 54) huían espantados, a pesar de ser "zuzurrados por sus padres" (ibid., p. 54). Estas secuencias continuadas muestran "imágenes exageradas e hipertrofiadas" (Bajtín, p. 1989: 19 y ss.) un cuerpo sucio, una vestimenta blanca, color que estéticamente desfigura aún más su silueta, un perfil monstruoso, estimulan la risa en un ámbito donde lo cómico y lo serio se presentan armónicamente.

Ante este escenario, en medio del tumulto carnavalesco la única mirada objetiva en el plano ficcional, aunque paradójica desde el punto de vista del receptor, y a pesar del susto que se lleva cuando su padre se desploma y se desparrama en el piso es la de Panchito.

El niño es quien le pregunta a su madre frente a la indeterminación de ella "¿qué hacemos mamá?” (Ribeyro, 1994: 53), líneas debajo, se presenta aún somnoliento y la interrumpe “Por qué hay tanta gente?” (ibid., p. 54), pregunta que continúa con una aseveración, con una sentencia que turba a su madre; "Papá no está muerto" (ibid., p. 54).

El hijo asegura que conversó con su padre mientras su madre iba a buscar a la vecina, el momento de máxima tensión ha llegado, los asistentes exclaman que el muerto está vivo. Al mismo tiempo, se produce el reconocimiento de la verdad, y esta "es la esencia misma del carnaval, y los que intervienen en el regocijo lo experimentan vivamente" (Bajtín, 2003, p. 9). Los individuos que por distintos motivos han asistido a la ceremonia donde es celebrado el carnaval no pueden escapar "porque el carnaval no tiene ninguna frontera espacial. [...] sólo puede vivirse de acuerdo a sus leyes, es decir de acuerdo a las leyes de la libertad" (ibid., p. 9). 
De pronto se destaca "un movimiento general de sorpresa, pero al mismo tiempo de decepción. Y al influjo de aquella gritería Moisés abrió los ojos” (Ribeyro, 1994, p. 55) se despierta en medio del supuesto velatorio y gritando pide un vaso de agua para aplacar el calor que le produjo la ingesta excesiva de alcohol.

Moisés "se reía con su labio leporino rodeado de los vecinos que, en lugar de felicitarlo, parecían exigir de él alguna disculpa” (ibid., p. 55). La ocurrencia es el latiguillo que modula el microepisodio sustentado por la participación de este personaje grotesco que no tiene acabado el cuerpo, en este sentido señala Bajtín que el mundo exterior le penetra por todos los orificios, boca, nariz, barriga (2003, p.25).

Moisés vuelve al estado de conciencia, regresa "de su desmayo [...] como de una siesta” (Ribeyro, 1994, p. 51), para recibir de manos del enfermero el pinchazo que lo aplaca, le "clavó una inyección en la nalga" (ibid., p. 56). El predominio del plano cómico sobre el serio eleva una imagen y la ordena en un nivel superior dando lugar al chiste.

La risotada de Moisés que deviene por consecuencia de las cosquillas se presenta cuando este se ve cara a cara con el enfermo, que al auscultarlo con el instrumento médico le provoca risa. Stern se pregunta si esa carcajada expresa algo trascendente, quizás algo moral, espiritual, social o axiológico y continúa realizando algunas reflexiones ante esta situación, explica que la literatura científica también la ha estudiado. Deduce que, en efecto, cuando la sonrisa es provocada por las cosquillas, es una risa instintiva, primitiva, por ende "parece ser la más alejada de toda expresión espiritual" (Stern, 1950, p. 121).

\section{Una broma malvada aviva al llanto carente de lágrimas}

Stern considera que el "ridículo mata" tal como lo afirman los franceses, esto es, si la risa mata valores "se vuelve trágica" (1950, p 51), para este autor si alguien se ríe de una persona o de aquello que produce esa persona en un contexto de seriedad es factible que el sujeto se enoje. Esta situación es análoga al desborde emocional por el que transita Mercedes y que es provocado por Moisés. Su esposo hace que Mercedes se enoje y lo empuje para que aquel deje de hacer lo que estaba haciendo.

Moisés realiza una broma tonta, malvada, donde pone en peligro a la habitación, a la vivienda y a toda la familia, juega con fuego y no precisamente en un sentido literal. Esa gracia que realiza el esposo enfada a Mercedes y no porque no le guste reír o sea poco inteligente y no tenga sentido del humor. Mercedes ha demostrado en el relato que a pesar de su magma interior quiere encontrar salidas del laberinto en donde ha sido arrojada, ella se ofusca porque su marido ha intentado degradar su valor y el del hijo de ambos.

En este contexto tenso, la broma es negativa y es recibida como un desajuste, una desproporción que puede aniquilar con lo moral, con lo sustantivo que es la 
vida individual, con lo económico, lo poco que la familia tiene como patrimonio ganancial. El conjunto de valores que reside en Mercedes ha sido atacado por su esposo, este hecho evidencia el menguado o nulo afecto que habita en el hogar dado que el enojo es severo, si hubiera simpatía habría mayor tolerancia. En fin, aquí la risa es un no - valor porque no mantiene "el equilibrio en el mundo de los valores" (Stern, 1950, p. 61), se trata de una risa que linda con lo trágico, con lo inferior, con lo grotesco.

En el polo opuesto de la risa se asienta el llanto, expresión que no se efectúa en la diégesis, pero que indirectamente lo contiene. Mercedes siente que sus valores hacia el futuro están amenazados, otros como el amor, se han degradado sino perdido y otros, aunque los desee con todas sus fuerzas son irrealizables. Para Stern el llanto expresa un doble carácter, emite juicios tanto positivos como negativos a la vez.

Lo positivo se manifiesta "con referencia a valores irrealizables, amenazados o perdidos" (ibid., p. 66) y lo negativo se expresa "con referencia a [...] esa pérdida" (ibid., p. 66). Moisés ha perdido el sentido común, la razón, la bebida ha movilizado sus pasiones, es la tara manifiesta en el hogar.

Mientras la vela se apaga, Mercedes siente "unas ganas invencibles de llorar" (Ribeyro, 1994, p. 57). La vela encendida es símbolo de luz, sustento para la imaginación, si se apaga la oscuridad ensombrece la escena.

\section{La antesala de lo trágico y lo trágico en el final}

La literatura contiene pórticos de entrada, zonas que pueden ubicarse como espacios vestibulares de la obra en sí misma, independientemente de que el autor haya escrito una poética después de que escribió un par de relatos, este conjunto de normas establecidas para relatar una ficción ocupa si así lo dispusiera el lector una antesala literaria. Asimismo, dentro del texto de la ficción se puede diseñar un espacio previo al núcleo de la historia, como lo designó Dante Alighieri, en la famosa Comedia adjetivada por Bocaccio como Divina, antes del cono infernal ubicó el limbo, umbral de un territorio espantoso.

Es el vestíbulo el lugar que antecede al espacio principal, muchos personajes o invitados permanecen en él y jamás se enteran en qué devienen los siguientes espacios, otros ingresan a la sala de invitados por el "dueño" (un personaje, el narrador) de la casa o el autor de la obra. Sea como sea, no todos los personajes o "seres de papeles" (Barthes, 1970, p. 33) tienen el privilegio de permanecer en el centro del edificio.

El humor en este episodio conforma esa zona reducida, ese espacio previo, no ingresa de lleno en la temática ribeyriana sino más bien la bordea tangencialmente, y se manifiesta de esta manera porque en esta familia "hay valores intrínsecos en peligro de pérdida" (Stern, 1950, p. 140). 
El efecto buscado y logrado que Ribeyro, como artesano, plantea en la trama arquitectural es un ocurrente cambio de tono en la pieza, que genera a la vez en el receptor que está fuera del texto, un efecto emocional imprevisto. Ante la desventura que circunda al relato, coloca el humor en el pasillo de la tragedia, antecede al fatal clima trágico que se desencadenará en el desenlace. Lo extraño de este final siniestro es que no contiene llanto ni lo causa, ni dentro, ni fuera de la ficción, por ende, se infiere que resulta así porque ninguno de los "seres de papel" o sujetos que participan de la obra se sienten identificados con el antihéroe, no lloran porque no sienten ni compasión ni temor (como lo desarrolla Aristóteles en La Poética) por Moisés.

El pequeño episodio humorístico se conecta con el cierre trágico de la mano de Mercedes. Ella, tal Eva pecadora, es quien deja cerca de Moisés la botella de aguardiente - elemento negativo que funciona como llamador - que "fue colocada al lado del nivel, de la plomada, de las espátulas salpicadas de yeso" (Ribeyro, 1994, p. 57), con el único cometido de que su esposo se envenene a sorbos y lentamente, para que beba "veneno por licor suave". ${ }^{6}$ Es la esposa la que le acerca el refresco prohibido por el enfermero para propiciarle una "herida que duele y no se siente". Es evidente, como sentencia Stern "que lo cómico de esta historia consiste en la degradación del valor moral del cariño conyugal” (1950, p. 131). Pues, el valor del amor del matrimonio queda reducido aquí al desencanto y a la contrariedad.

\section{Consideraciones finales}

La escena "irradia, sobre una multitud de otras escenas, lo cómico que en sí misma contiene" (Bergson, 1985, p. 38). El episodio de Moisés es irrisorio porque se producen desplazamientos en más de un nivel. Se alternan desniveles que permanecen compuestos por desajustes morales, económicos, físicos, que acentúan la risa en el receptor; y a pesar de la persistencia de la angustia casi pesadillesca (en sentido kafkiano) que sobrevuela el espacio de la vivienda, el efecto que promueve Moisés con sus actitudes grotescas es el rasgo distintivo que brinda la nota humorística porque produce la fractura semántica. Dado el tono del relato y de toda la obra no es esperable que la risa llegue en una escena que se carga de pathos. Es verdad que no es un pathos sublime que promueva emociones fuertes, suficiente para desprender del sujeto que recibe la obra la catarsis o la conmiseración de las pasiones, como lo reivindica el estagirita Aristóteles, pero no es menor el hecho de que la esposa planee la muerte de quien duerme junto a ella a diario.

De la misma manera que la risa sorprende en el contexto del relato, asombra la no presencia del llanto, los personajes a pesar de la miseria exterior (e interior) que

6 E1 soneto 26 de Lope de Vega, expone las emociones internas por las que transita el yo lírico al definir el amor.

7 El soneto amoroso de Francisco de Quevedo expresa las contradicciones del amor mientras se lo define. 
habitan no vociferan una reflexión personal hacia alguien o algo que los trascienda, tampoco la lágrima asoma como muestra de dolor y sufrimiento. Los protagonistas no son dignos de lástima. El narrador muestra en ellos cierta justicia "terrestre", que prueba que estos sujetos padecen debido a que no existe salida posible. Ni siquiera el fundamento espiritual tiene asidero en el breviario de Los gallinazos sin plumas, porque el mérito de ese libro reside en "la unidad del conjunto, (...) en la materia trabajada", (Ribeyro, 2003, p. 47) y aunque "la visión resulta al final un poco miserable" (ibid., p. 47) es "exacta y verosímil” (ibid., p. 47).

En La tentación del fracaso, Ribeyro busca "lo absoluto (...). Tal vez esté en los viajes que aún no he realizado (...) o en Dios, a quien creo haber perdido" (ibid., p. 12), ese escepticismo se hace extensible a otros personajes anteriores a esa obra.

El desplazamiento de valores funciona también a nivel de personaje - receptor, Moisés ha devenido en el aniquilamiento individual, por falta de apego a los afectos, a los elementos que lo unen a la vida, tanto le da estar somnoliento como despierto. Sus escalas de valores se han alterado y con ello ha modificado su entorno.

En efecto, se produce un quiebre de todos los valores, Moisés has resultado ser el payaso cómico del carnaval, es el blanco donde dispara la risa, su dimensión ética "aquello que denominamos su existencia moral" (Stern, 1950, p. 52) se ha desvanecido.

Para Stern al igual que para Bergson lo cómico produce un quiebre de nivel, una desproporción, ante la perspectiva del que mira, esto es, si se enfoca solo a un lado "moral" del personaje y de repente ese plano gira y lo ético que ocupa un lugar serio en la escena se desplaza hacia un lateral que ocupa a lo "físico", altera a la vez el foco atencional del receptor. Esta inversión procedimental o artificio mecánico que actúa súbitamente suscita por lo general, risa ante el espectador.

Bergson lo resume de este modo: "es cómico todo incidente que atrae nuestra atención sobre la parte física de una persona cuando nos ocupábamos de su aspecto moral" (1985, p. 25). Es factible que el antihéroe carezca de grandezas o profundidades estéticas, espirituales, sagradas, laborales, pues se han desintegrado en el momento mismo en el que Moisés irrumpe en escena.

Para que algo sea considerado cómico debe expresar cierta expresión actitudinal señala Henri Bergson, para el teórico, los gestos y las formas forman parte de la caricatura, imprimen fuerza, dinamismo. La risa es una contorsión necesaria, aún en objetos naturales de la fisonomía humana, "en la curva de una nariz, en la forma de una oreja" (ibid., p. 19). Bergson coincide en este punto con Stern, cuando un hombre tropieza, cae y sale ileso, para Bergson es la torpeza de quien camina y esa distracción fatal, es la que hace reír. 
A Moisés su cara y cuerpo le estorban, su forma corporal concibe el asidero exacto para lograr el humor, que además de significar inteligencia, es vehículo por donde transita el arte.

\section{Referencias}

Bachelard, G. (1978). El agua y los sueños: ensayo sobre la imaginación de la materia. (Trad. I. Vitale,) México: FCE.

- (2006). La poética del espacio. (Trad. E. de Champourcín.) México: FCE.

Bajtín, M. (1989). Teoría y estética de la novela. Traducción de Helena Kriúkova y Vicente Cazcarra, Madrid: Taurus.

- (2003). La cultura popular en la Edad Media y el Renacimiento. Versión de Julio Forcat y César Conroy. 3 ed. Madrid: Alianza.

Barthes, R., Greimas, A., Bremond, C., Gritti, J, Morin, V. y otros. (1970). Comunicaciones. Análisis estructural del relato. (Trad. Beatriz Dorriots). Buenos Aires: Editorial Tiempo Contemporáneo.

Bergson, H. (1985). La risa. (Trad. Amalia Aydée Raggio). Madrid: Sarpe.

Cirlot, J. E. (1992). Diccionario de simbolos. Barcelona: Labor S.A.

Eliade, M. (1991). Mito y realidad. Barcelona: Labor.

Elmore, P. (2002). El perfil de la palabra. Lima: Fondo Cultura Económica.

Esteban, Á. (2014). El flaco Julio y el escribidor. Sevilla: Renacimiento.

Flores, G. Morales, J. Martos, M. (Comp.). (2014). Ribeyro por tiempo indefinido. Lima: Cátedra Vallejo.

Navascués, J. (2004). Los refugios de la memoria. Madrid: Iberoamericana.

Ribeyro, J. R. (1994). La palabra del mudo. Lima: Jaime Campodónico.

- (2003). La tentación del fracaso. Barcelona: Seix Barrial.

Zavaleta, C. (2006). Narradores peruanos de los 50. Lima: Instituto Nacional de Cultura.

Stern, A. (1950). Filosofía de la risa y del llanto. Panorama de la Filosofía y de la Cultura IV. (Trad. Julio Cortázar). Buenos Aires: Imán. 